\title{
DETERMINASI RASIO KEUANGAN TERHADAP RETURN SAHAM
}

\author{
Dian Yunita Syaiful \\ Fakultas Ekonomi dan Bisnis Universitas Trunojoyo Madura \\ dian.yunita046@yahoo.com
}

\begin{abstract}
Return or the return on investment is a prime destination for investors in investing at a company. Stock investment will provide a benefit or return by the way, is the first to sell the stock until the price is strong, often referred to as capital gains or waiting dividend, which is part of the company profits are distributed to shareholders. The company's financial statements can be used as a basis for investors to take a decision to invest in shares in a particular company by taking into account financial ratios of the company. This study aims to determine the effect and significance of the test ratio Current Ratio (CR), Debt to Equity Ratio (DER), Return on Equity (ROE), and Price Earning Ratio (PER) to return stock in LQ-45. period in this study is from the year 2009 until 2013. model of analysis used is multiple linear regression. The results showed partially significant effect on stock returns is the Current Ratio (CR), Return on Equity (ROE), and Price Earning Ratio (PER) where ROE is the dominant variable significant positive effect on stock returns. Simultaneously Current Ratio (CR), Debt to Equity Ratio (DER), Return on Equity (ROE), and Price Earning Ratio (PER) has an effect on stock returns by $59 \%$, while $41 \%$ are influenced by other factors not examined in the study this.
\end{abstract}

Keywords: Current Ratio (CR), Debt to Equity Ratio (DER), Return On Equity (ROE), Price Earning Ratio (PER), Stock Return.

\section{PENDAHULUAN}

Dalam melakukan investasi pada saham, harapan yang diinginkan investor adalah memperoleh return, dimana return disini adalah keuntungan yang diterima karena adanya selisih antara harga jual dengan harga beli saham suatu instrumen investasi yang disebut capital gain dan dividend. Capital gain sangat bergantung dari harga pasar instrument investasi, yang berarti bahwa instrumen investasi harus diperdagangkan dipasar. Dengan adanya perdagangan maka akan timbul perubahan nilai suatu instrument investasi yang memberikan captal gain. Besarnya capital gain dilakukan dengan analisis return histories yang terjadi pada periode sebelumnya, sehingga dapat ditentukan besarnya tingkat kembalian (expected return). Penilaian investor terhadap suatu saham perusahaan diantaranya adalah dengan memperhatikan kinerja perusahaan yang menerbitkan saham. Oleh karena itu, return saham sangat penting bagi perusahaan karena digunakan sebagai salah satu pengukur kinerja dari suatu perusahaan, sehingga perusahaan berusaha menjaga dan memperbaiki kinerjanya yang dapat mempengaruhi return saham agar portofolio saham yang diinvestasikan meningkat.

Alasan memilih saham LQ 45 sebagai obyek penelitian karena saham LQ 45 merupakan saham-saham yang paling aktif diperdagangkan dalam Bursa Efek Indonesia dan merupakan saham-saham unggulan yang dipilih dari tiap-tiap sektor industri sehingga dapat lebih akurat dalam analisisnya secara runtut waktu (time series). 
Peneliti memilih variabel CR karena rasio lancar (current ratio) merupakan indikator terbaik sampai sejauh mana klaim dari kreditur jangka pendek telah ditutup oleh aktiva-aktiva yang diharapkan dapat diubah menjadi kas dengan cukup cepat, rasio ini merupakan ukuran solvabilitas jangka pendek yang paling sering digunakan (Brigham dan Houston; 2006). Rasio lain yang diperkirakan juga dapat mempengaruhi return suatu saham adalah DER. DER merupakan rasio solvabilitas yang mengukur kemampuan kinerja perusahaan dalam mengembalikan hutang jangka panjangnya dengan melihat perbandingan antaratotal hutang dengan total ekuitasnya (Ang, 1997). Return on Equity (ROE) juga merupakan salah satu rasio profitabilitas yang digunakan investor untuk mengetahui kemampuan perusahaan atas keseluruhan dana yang ditanamkan dalam aktivitas yang digunakan untuk aktivitas operasi perusahaan dengan tujuan menghasilkan laba dengan memanfaatkan aktiva yang dimilikinya (Ang, 1997). PER menggambarkan apresiasi pasar terhadap kemampuan perusahaan dalam menghasilkan laba. PER sebagai indikator kepercayaan pasar modal terhadap pertumbuhan perusahaan. Banyak investor di pasar modal yang menaruh perhatian pendekatan terhadap PER.

\section{TINJAUAN PUSTAKA DAN HIPOTESIS}

\subsection{Pasar Modal}

Menurut Samsul (2006), pasar modal adalah tempat atau sarana bertemunya antara permintaan dan penawaran atas instrumen keuangan jangka panjang, umumnya lebih dari satu tahun. Sedangkan menurut Fahmi dan Hadi (2011), pasar modal adalah tempat dimana berbagai pihak khususnya perusahaan menjual saham (stock) dan obligasi (bond) dengan tujuan dari hasil penjualan tersebut nantinya akan dipergunakan sebagai tambahan dana atau untuk memperkuat dana perusahaan. Dari dua definisi tersebut, dapat disimpulkan bahwa pasar modal adalah tempat bertemunya antara permintaan dan penawaran atas instrumen keuangan jangka panjang yang biasanya diperjualbelikan umumnya lebih dari satu tahun yang dipergunakan sebagai tambahan dana atau untuk memperkuat dana perusahaan.

\subsection{Return Saham}

Return merupakan hasil yang diperoleh dari investasi. Return dapat berupa return realisasi yang sudah terjadi atau return ekpektasi yang belum terjadi tetapi diharapkan akan terjadi di masa mendatang. Return realisasi (realized return) merupakan return yang telah terjadi. Return realisasi dihitung berdasarkan data historis. Return realisasi penting karena digunakan sebagai salah satu pengukur kinerja dari perusahaan. Return historis ini juga berguna sebagai dasar penentuan return ekspektasi (expected return) dan risiko di masa datang. Return ekspektasi (expected return) adalah return yang diharapkan akan diperoleh oleh investor di masa mendatang. Berbeda dengan return realisasi yang sifatnya sudah terjadi, return ekspektasi sifatnya belum terjadi (Jogianto, 2000:107). Adapun return saham dapat dihitung dengan menggunakan rumus (Jogiyanto, 2000):

Dimana:

$$
R t=\left(\frac{P_{t}-P_{t-1}}{P_{t-1}}\right)
$$

$\mathrm{Rt}=$ Return saham pada hari ke $t$

$\mathrm{Pt}=$ Harga saham pada periode ke $t$

Pt-1= Harga saham pada periode ke $t-1$

\subsection{Saham LQ 45}

Indeks LQ 45 merupakan jenis indeks yang terdiri dari 45 saham yang paling aktif diperdagangkan. Pertimbangan-pertimbangan yang mendasari pemilihan yang masuk di Indeks LQ 45 adalah likuidasi dan kapitalisasi pasar dengan kriteria sebagai berikut: 
a. Masuk ke dalam rangking 60 besar dari total transaksi saham di pasar regular (rata-rata nilai transaksi selama 12 bulan terakhir).

b. Rangking berdasarkan kapitalisasi pasar (rata-rata kapitalisasi pasar 12 bulan terakhir).

c. Telah tercatat di BEI minimum 3 bulan.

d. Keadaan keuangan perusahaan dan prospek pertumbuhannnya, frekuensi, dan jumlah hari perdagangan transaksi pasar reguler. Saham-saham di LQ 45 terus dipantau. Pergantian saham akan dilakukan setiap enam bulan sekali, yaitu pada awal bulan Februari dan awal bulan Agustus.

\subsection{Rasio Keuangan Current Ratio (CR)}

Rasio yang paling umum digunakan untuk menganalisa posisi modal kerja suatu perusahaan (likuiditas) adalah dengan menggunakan current ratio (CR). Rasio ini menunjukkan perbandingan nilai kekayaan lancar (yang segera dapat dijadikan uang) dengan hutang jangka pendek (Munawir, 2001). Menurut Husnan (2002), current ratio adalah rasio yang mengukur sejauh mana kemampuan aktiva lancar perusahaan biasa dipergunakan untuk memenuhi kewajiban lancarnya. Secara matematis CR dapat dirumuskan sebagai berikut:

$$
C R=\frac{\text { AktivaLancar }}{\text { Kewajiban Lancar }}
$$

\section{Debt to Equity Ratio (DER)}

Debt to Equity Ratio selain digunakan untuk melihat struktur permodalan perusahaan juga bisa digunakan untuk melihat tingkat solvabilitas (penggunaan hutang) terhadap total shareholder's equity (Ang, 1997). DER yang tinggi menandakan modal usaha lebih banyak dibiayai oleh hutang dibandingkan dengan penggunaan modal sendiri. Secara matematis DER dapat dirumuskan sebagai berikut (Ang, 1997):

$$
D E R=\frac{\text { Total Hutang }}{\text { Total Ekuitas }}
$$

\section{Return On Equity (ROE)}

Return On Equity (ROE) digunakan untuk mengukur tingkat pengembalian perusahaan atau efektivitas perusahaan di dalam menghasilkan keuntungan dengan memanfaatkan ekuitas (shareholders' equity) yang dimiliki oleh perusahaan. Return On Equity (ROE) adalah kemampuan perusahaan dalam menghasilkan keuntungan dengan modal sendiri yang di miliki, sehingga retun on equity ini ada yang menyebutnya sebagai rentabilitas modal sendiri. (Hadi, 2000:197). ROE dapat dirumuskan sebagai berikut:

$$
R O E=\frac{\text { Earning After Interest and Tax }}{\text { Equitas }}
$$

\section{Price Earning Ratio (PER)}

Menurut Hanafi dan Mamduh (2009) rasio pasar adalah rasio yang mengukur harga pasar relatif terhadap nilai buku. Sudut pandang rasio ini lebih banyak berdasar pada sudut pandang investor (calon investor), meskipun pihak manajemen juga berkepentingan terhadap rasio ini. Perusahaan dengan peluang tingkat pertumbuhan yang tinggi biasanya memiliki PER yang tinggi, sebaliknya perusahaan dengan tingkat pertumbuhan yang rendah cenderung memiliki PER yang rendah pula (Prastowo dan Juliaty, 2005). PER dapat dirumuskan sebagai berikut:

$$
P E R=\frac{\text { Harga Pasar Saham }}{\text { Laba Bersih }}
$$




\subsection{Pengembangan Hipotesis}

\subsubsection{Pengaruh Current Ratio (CR) terhadap return saham}

Rasio likuiditas digunakan untuk mengukur kemampuan perusahaan untuk memenuhi kewajiban jangka pendeknya. CR digunakan untuk mencari nilai likuiditas tersebut. CR didapatkan dengan membandingkan nilai aktiva lancar dengan kewajiban lancar perusahaan. Semakin tinggi nilai CR berarti semakin baik kemampuan perusahaan untuk melunasi kewajiban jangka pendeknya.

\subsubsection{Pengaruh Debt to Equity Ratio (DER) terhadap return saham}

DER memberikan gambaran kemampuan perusahaan melunasi seluruh utangnya bila dibandingkan dengan modal yang dimiliki. Meningkatnya nilai DER berarti meningkatnya jumlah utang yang dimiliki oleh perusahaan. Disisi lain, peningkatan DER bisa juga disebabkan karena nilai modal sendiri yang dimiliki jauh lebih kecil bila dibandingkan dengan utang dari pihak eksternal. Hal ini akan menyebabkan perusahaan sangat tergantung pada kreditur. Hal ini menyebabkan para investor ragu menanamkan modalnya pada perusahaan karena resiko utang yang tinggi. DER yang terlalu tinggi mempunyai dampak buruk terhadap kinerja perusahaan, karena tingkat utang yang semakin tinggi berarti beban bunga perusahaan akan semakin besar dan akan mengurangi keuntungan.

\subsubsection{Pengaruh Return On Equity (ROE) terhadap return saham}

ROE merupakan ukuran kemampuan perusahaan dalam menghasilkan keuntungan dengan menggunakan modal sendiri, sehingga ROE sering disebut sebagai rentabilitas modal sendiri. Tingkat ROE yang tinggi menunjukkan kemampuan perusahaan dalam menghasilkan laba bagi pemegang saham. Jika perusahaan dapat menghasilakn laba yang tinggi, maka permintaan akan saham akan meningkat dan selanjutnya akan berdampak pada meningkatnya harga saham perusahaan. Ketika harga saham semakin meningkat maka return saham juga akan meningkat. Penelitian yang dilakukan oleh sari (2012), Widodo (2007), Jauhari dan Wibowo (2004) menunjukkan bahwa ROE mempunyai pengaruh terhadap return saham.

\subsubsection{Pengaruh Price Earning Ratio (PER) terhadap return saham}

PER merupakan perbandingan antara harga pasar suatu saham dengan EPS dari saham yang bersangkutan. Makin besar PER suatu saham maka menyatakan saham tersebut semakin mahal terhadap pendapatan bersih per saham. Jika PER meningkat maka harga saham juga akan semakin besar begitu juga dengan return saham. Penelitian yang dilakukan oleh Savitri (2012) dan Pasaribu (2007) menyatakan bahwa PER mempunyai pengaruh terhadap return saham.

\section{METODE PENELITIAN}

\subsection{Jenis Penelitian dan Gambaran Populasi (Obyek) Penelitian}

Dalam melaksanakan penelitian ini, data yang dipergunakan adalah data sekunder yaitu data yang diterbitkan dan digunakan oleh organisasi. Data sekunder yang digunakan merupakan data yang diperoleh secara tidak langsung dari sumbernya, yang berupa Indeks Harga Saham LQ-45 periode 2009-2013 (dengan pertimbangan bahwa saham-saham perusahaan yang menjadi sampel termasuk dalam golongan saham LQ$45)$.

Indeks LQ 45 terdiri dari 45 emiten dengan likuiditas (LiQuid) tinggi, yang diseleksi melalui beberapa kriteria pemilihan. Selain penilaian atas likuiditas, seleksi atas emiten-emiten tersebut juga mempertimbangkan kapitalisasi pasar. 


\subsection{Teknik pengambilan Sampel}

Pemilihan sampel menggunakan teknik purposive sampling yaitu teknik penentuan sampel dengan pertimbangan tertentu (Sugiyono, 2007). Kriteria penentuan sampel adalah sebagai berikut:

a. Perusahaan menerbitkan laporan keuangan tahunan dari tahun 2009-2013.

b. Perusahaan selalu masuk dalam LQ 45 selama periode 2009-2013.

c. Ketersediaan dan kelengkapan data selama penelitian. Apabila ada perusahaan yang tidak bisa dihitung rasionya, maka akan dikeluarkan.

\subsection{Teknik Pengumpulan Data}

a. Penelitian Lapangan

Data yang digunakan dalam penelitian ini adalah data yang bersifat sekunder, yaitu data yang diperoleh di Bursa Efek Indonesia

b. Metode Kepustakaan

Untuk memperoleh tinjauan pustaka yang tepat maka peneliti membaca, mengutip serta menganalisa dari berbagai sumber bukubuku literatur, jurnal penelitian ilmiah dan tesis yang berkaitan dengan penelitian.

c. Internet Research

Untuk memperoleh data-data yang up - date maka peneliti juga melakukan internet research pada beberapa situs.

\subsection{Teknik Analisa Data}

Metode analisis yang digunakan adalah model regresi linier berganda yang persamaannya dapat dituliskan sebagai berikut:

$\mathrm{Y}=\mathrm{a}+\mathrm{b}_{1} \mathrm{X}_{1}+\mathrm{b}_{2} \mathrm{X}_{2}+\mathrm{b}_{3} \mathrm{X}_{3}+\mathrm{b}_{4} \mathrm{X}_{4}+\mathrm{e}$

keterangan:

$\mathrm{Y}=$ Return Saham

$\mathrm{X}_{1}=$ Current Ratio $(\mathrm{CR})$

$\mathrm{X}_{2}=$ Debt To Equity Ratio (DER)

$\mathrm{X}_{3}=$ Return On Equity (ROE)

$\mathrm{X}_{4}=$ Price Earning Ratio (PER)

b $1 \ldots$... b4 $=$ Koefisien regresi

$\alpha=$ konstanta

$\mathrm{e}=$ error term

Nilai koefisien regresi disini sangat menentukan sebagai dasar analisis, mengingat penelitian ini bersifat fundamental method. Hal ini berarti jika koefisien b bernilai positif $(+)$ maka dapat dikatakan terjadi pengaruh searah antara variabel bebas dengan variabel terikat (dependen), setiap kenaikan nilai variabel bebas akan mengakibatkan kenaikan variabel terikat (dependen). Demikian pula sebaliknya, bila koefisien nilai $b$ bernilai negatif (-), hal ini menunjukkan adanya pengaruh negatif dimana kenaikan nilai variabel bebas akan mengakibatkan penurunan nilai variabel terikat (dependen).

\section{HASIL PENELITIAN DAN PEMBAHASAN}

Dalam penelitian ini return saham sebagai variabel terikat sedangkan CR, DER, ROE, dan PER diperkirakan mempunyai pengaruh yang bermakna terhadap return saham yaitu sebagai variabel bebas. Dalam rangka memperoleh analisis yang memadai, maka upaya 
untuk mencapai tujuan tersebut dipilih 22 perusahaan yang berturut-turut masuk dalam kategori LQ-45 selama 5 tahun dari tahun 2009 sampai dengan tahun 2013.

\subsection{Hasil Penelitian}

Berdasarkan analisis regresi diperoleh hasil seperti pada tabel di bawah ini:

Tabel 2 Hasil Uji R dan F

\begin{tabular}{clc}
\hline No. & \multicolumn{1}{c}{ Parameter } & Hasil Uji \\
\hline 1 & R & $: .768$ \\
2 & R Square & $: .590$ \\
3 & F uji & $: 6.105$ \\
4 & Sig. & $: .003$ \\
5 & Durbin Watson & $: 2.060$ \\
\hline
\end{tabular}

Tabel 3 Hasil Uji Model Regresi

\begin{tabular}{llrrr}
\hline \multicolumn{1}{l}{ Model } & \multicolumn{2}{c}{$\begin{array}{c}\text { Koefisien } \\
\text { Regresi }\end{array}$} & $\mathrm{t}$ & Sig. \\
\hline 1 & (Constant) & 126.449 & 1.871 & .079 \\
& ROE & 3.941 & 3.950 & .001 \\
CR & 33.427 & 2.058 & .035 \\
PER & 14.224 & 1.912 & .043 \\
DER & -3.431 & -1.530 & .145 \\
\hline
\end{tabular}

Dari tabel 2, dapat diketahui bahwa setelah dilakukan analisis regresi ada 3 buah variabel yang berpengaruh signifikan terhadap return saham. Secara simultan (Uji F) variabel bebas berpengaruh terhadap return saham, hal ini dapat diketahui dari angka $F$ uji sebesar 6.105 dengan tingkat signifikansi sebesar 0.003 yang berada di bawah alpha 0.05 .

Sedangkan berdasarkan table 3 diketahui bahwa ada 3 variabel (ROE, CR, dan PER) berpangaruh signifikan terhadap return saham.

$$
\mathrm{Y}=126,449+3,941 \mathrm{ROE}+33,427 \mathrm{CR}+14,224 \mathrm{PER}-3.431 \mathrm{DER}
$$

\subsection{Pembahasan}

\subsubsection{Pengaruh Return of Equity (ROE) terhadap return saham}

Hasil pengujian hipotesis menunjukkan bahwa nilai signifikansi sebesar 0,001 (lebih kecil dari 0,05) yang berarti bahwa ROE berpengaruh positif dan pengaruhnya signifikan terhadap return saham. Hasil penelitian ini menujukkan bahwa perubahan nilai ROE akan memberikan kontribusi yang positif dan signifikan terhadap return saham LQ 45, yaitu kenaikan atau penurunan nilai ROE akan berdampak pada kenaikan atau penurunan return saham, nilai ROE yang semakin tinggi akan memberikan kontribusi terhadap return saham LQ 45 yang semakin tinggi atau sebaliknya. 


\subsubsection{Pengaruh Current Ratio (CR) terhadap return saham}

Hasil pengujian hipotesis menunjukkan bahwa nilai signifikansi sebesar 0,0035 (lebih kecil dari 0,05) yang berarti bahwa CR berpengaruh positif dan pengaruhnya signifikan terhadap return saham. Hasil penelitian ini menunjukkan bahwa CR yang rendah akan menyebabkan terjadi penurunan harga pasar dari harga saham yang bersangkutan. CR yang tinggi dapat disebabkan adanya piutang yang tidak tertagih dan persediaan yang belum terjual, yang tentunya tidak dapat digunakan secara cepat untuk membayar hutang. Hasil penelitian ini mendukung hasil penelitian yang dilakukan oleh Ulupui (2005) yang memperlihatkan hasil bahwa CR berpengaruh signifikan terhadap return saham.

\subsubsection{Pengaruh Price Earning Ratio (PER) terhadap return saham}

Hasil pengujian hipotesis menunjukkan bahwa nilai nilai signifikansi sebesar 0,0043 (lebih kecil dari 0,05) yang berarti bahwa PER berpengaruh signifikan terhadap return saham. Hasil penelitian ini menujukkan bahwa perubahan nilai PER akan memberikan kontribusi yang positif dan signifikan terhadap return saham LQ 45, yaitu kenaikan atau penurunan nilai PER akan berdampak pada kenaikan atau penurunan return saham, nilai PER yang semakin tinggi akan memberikan kontribusi terhadap return saham LQ 45 yang semakin tinggi atau sebaliknya.

\subsubsection{Pengaruh Debt To Equity Ratio (DER) terhadap return saham}

Hasil pengujian hipotesis menunjukkan bahwa nilai signifikansi sebesar 0,145 (lebih besar dari 0,05) yang berarti bahwa DER berpengaruh tidak signifikan terhadap return saham.

Dari pembahasan yang telah dibahas di atas, dapat diketahui bahwa variabel yang dominan mempengaruhi return saham adalah ROE yang dibuktikan dengan hasil perhitungan statistik dengan nilai signifikansi 0,001 yang lebih kecil dari variabel CR dan PER yaitu sebesar 0,035 dan 0,043.

\section{SIMPULAN DAN SARAN}

\subsection{Simpulan}

Berdasarkan hasil analisis data dan pengujian hipotesis yang telah diuraikan pada bab sebelumnya, maka dapat diperoleh kesimpulan sebagai berikut :

a. Hasil pengujian secara parsial (Uji Statistik t) menunjukkan bahwa variabel Return of Equity (ROE) berpengaruh signifikan terhadap return saham, Current Ratio (CR) berpengaruh signifikan terhadap return saham, Price Earning Ratio (PER) berpengaruh signifikan terhadap return saham, dan Debt To Equity Ratio (DER) tidak berpengaruh signifikan terhadap return saham.

b. Hasil pengujian secara simultan (Uji Statistik F) menunjukkan bahwa variabel Return of Equity (ROE), Current Ratio (CR), Price Earning Ratio (PER), dan Debt To Equity Ratio (DER) secara bersama-sama berpengaruh signifikan terhadap Return Saham.

\subsection{Saran}

a. Penelitian selanjutnya diharapkan dapat dilakukan pada objek bidang perusahaan yang spesifik, sehingga dapat menggambarkan pengaruh dari variabel-variabel independen terhadap return saham pada bidang tertentu.

b. Penelitian selanjutnya dapat melanjutkan penelitian ini dengan menggunakan sample yang lebih banyak dan periode penelitian yang lebih panjang serta dapat 
mempetimbangkan menggunakan variabel fundamental internal dan eksternal perusahaan.

\section{DAFTAR PUSTAKA}

Ang, Robert.(1997). Buku Pintar Pasar Modal Indonesia. Jakarta: Media Staff Indonesia.

Atmajaya, Lukas Setia. (2009). Statistika Untuk Bisnis Dan Ekonomi. Andi, Yogyakarta.

Babaei, Alireza. (2014). Evaluation the principal components of accounting and its impact on the stock returns of listed companies in Tehran Stock Exchange. New York Science Journal 2014;7(7).

Brigham, Eugene F and Joel F.Houston, (2006). Dasar-Dasar Manajemen Keuangan, alih bahasa Ali Akbar Yulianto, Buku satu, Edisi sepuluh, PT. Salemba Empat, Jakarta.

Chairatanawan, Yongyoot. (2008). Predictive Power of Financial Ratios to Stock Return in Thailand. Institute of International Studides, Ramkhamhaeng University. RU Int J. Vol 2 (2). Bangkok, Thailand.

Christanti, Yurike, (2009). Analisis Pengaruh Rasio Likuiditas, Leverage, Aktivitas, Profitabtlitas, dan Nilat Pasar Terhadap Return Saham (Studi Pada Perusahaan Manufaktur yang Terdaftar di BEI) . FE-univ. Andalas

Fahmi, Irham. (2011). Analisis Laporan Keuangan. Alfabeta. Bandung.

Fahmi, Irham dan Hadi, Yovi Lavianti. (2009). Teori Portofolio dan Analisis Investasi. Alfabeta. Bandung.

Fahmi, Irham dan Hadi, Yovi Lavianti. (2011). Teori Portofolio dan Analisis Investasi. Alfabeta. Bandung.

Ghozali, Imam, (2005). Aplikasi Analisis Multivariate dengan Program Spss, Penerbit Universitas Diponegoro.

Ghozali, Imam, (2009). Aplikasi Analisis Multivariate dengan Program Spss, Edisi Keempat, Penerbit Universitas Diponegoro.

Gujarati, Damodar. (2003). Ekonometrika Dasar., Jakarta: Erlangga.

Hadi, Sutrisno. (2000). Metodologi Research. Yogyakarta : Andi Yogyakarta.

Hamka, Arman M.S. (2012). Pengaruh Variabel Earning per Share (EPS), Price Earning Ratio (PER), dan Return on Equity (ROE) Terhadap Harga Saham (Studi 
Pada Perusahaan Pertambangan yang Terdaftar di Bursa Efek Indonesia). Fakultas Ekonomi dan Bisnis Universitas Brawijaya.

Hanafi, Mamduh M dan Halim, Abdul. (2009). Analisis Laporan Keuangan. UPP STIM YKPN. Yogyakarta.

Hartono, Jogiyanto. (2009). Teori Portopolio dan Analisis Investasi Edisi Keenam. BPFE. Yogyakarta.

Hasan, M. Iqbal. (2002). Pokok-pokok Materi Metodologi Penelitian dan Aplikasinya, Ghalia Indonesia, Bogor.

Helfert, Erich A. (1997). Teknik analisis keuangan : petunjuk praktis untuk mengelola \& mengaturkinerja perusahaan, edisi kesembilan. Jakarta : Erlangga.

Hernendiastoro, Andre. (2005). Pengaruh Kinerja Perusahaan Dan Kondis Ekonomi Terhadap Return Saham Dengan Metode Intervalling (Studi Kasus Pada SahamSaham LQ 45. Tesis. Semarang: Universitas Diponegoro.

Jogiyanto. (2000). Teori Portofolio dan Investasi. Edisi Pertama. Yogyakarta: BPFEUGM.

Jauhari, Budi Rusman dan Wibowo, Basuki. (2004). Analisis Fundamental Terhadap Return Saham pada Periode Bullish dan Bearish Indeks Harga Saham Gabungan. Jurnal Akuntansi dan Keuangan Vol. 9 No. 2 Hal. 17-32

Kasmir. (2008). Analisis Laporan Keuangan. PT. Raja Grafindo Persada. Jakarta.

Kusumo, RM Gian Ismoyo. (2011). Analisis Pengaruh Rasio Keuangan terhadap Return Saham pada Perusahaan Non Bank LQ 45. Universitas Diponegoro. Semarang.

Munawir. (2007). Analisis Laporan Keuangan.. Liberty. Yogyakarta.

Poernamawati, Fahmi. (2008). Pengaruh Price Book Value (PBV) dan Price Earning Ratio (PER) Terhadap Return Saham Perusahaan Manufaktur yang Terdaftar di BEI. Malang: Jurnal Manajemen Universitas Gajayana, Vol. 5 No. 2, November 2008, 105-108.

Prastowo, Dwi dan Juliaty, Rifka. (2005). Analisis Laporan Keuangan. UPP STIM YKPN. Yogyakarta.

Prihartini, Ratna. (2009). Analisis Pengaruh Inflasi, Nilai Tukar, ROA, DER, dan CR Terhadap Return Saham (Studi Kasus Saham Industri Real Estate and Property yang Terdaftar di Bursa Efek Indonesia Periode 2003-2006). Tesis. Semarang: Universitas Diponegoro. 
Restiyani, D. (2006). Analisis Pengaruh Faktor Fundamental Terhadap Return Saham (Studi Kasus Pada Perusahaan Otomotif dan Komponennya di BEJ Periode 2001 2004). Universitas Diponegoro Semarang.

Riyanto, Bambang. (1995), Dasar-dasar pembelanjaan perusahaan, Edisi keempat, Yogyakarta, Yayasan Penerbit Gajah Mada.

Riyanto, Bambang. (2008). Dasar-Dasar Pembelanjaan Perusahaan. BPFE. Yogyakarta.

Ruky, Saiful M. (1992). Menilai Penyertaan Dalam Perusahaan, Jakarta: Gramedia Pustaka Utama.

Samsul, Muhammad. (2006). Pasar Modal dan Manajemen Portofolio. Gelora Aksara Pratama. Surabaya.

Sartono, Agus. (1998). Manajemen Keuangan Teori dan Aplikasi. Yogyakarta: BPEF

Sartono, Agus. (2001). Manajemen Keuangan Teori dan Aplikasi. Yogyakarta: BPEF

Savitri, Dyah Ayu. (2012). Analisis Pengaruh ROA, NPM, EPS dan PER terhadap Return Saham. Universitas Diponegoro. Semarang.

Sekaran, Uma. (2006). Metodologi Penelitian untuk Bisnis. Jilid 1. Edisi 4. Salemba Empat: Jakarta.

Suharli, Michell. 2(005). Studi Empiris Terhadap Dua Faktor Yang Mempengaruhi Return Saham Pada Industri Food \& Beverages Di Bursa Efek Jakarta. Jurnal Akuntansi \& Keuangan, vol. 7 no. 2, Nopember, hal. 99 - 116.

Susilawati, Yeye dan Turyanto, Tri. (2009). Reaksi Signal Rasio Profitabilitas dan Rasio Solvabilitas terhadap Return Saham Perusahaan. Dinamika Keuangan dan Perbankan Mei 2011 Hal. 17-37 Vol. 3 No.1

Syamsuddin, Lukman. (2000). Manajemen Keuangan Perusahaan. PT. Raja Grafindo. Jakarta.

Syamsuddin, Lukman. (2009). Manajemen Keuangan Perusahaan : Konsep Aplikasi dalam : Perencanaan, Pengawasan, dan Pengambilan Keputusan. Jakarta: Rajawali Pers.

Ulupui, IGKA. (2005). Analisis Pengaruh Rasio Likuiditas, Leverage, Aktivitas, dan Profitabilitas Terhadap Return Saham (Studi PadaPerusahaan Makanan dan Minuman Dengan Kategori Industri Barang Konsumsi di BEJ). Jurnal Akuntansi, Bali: Universitas Udayana.

Weygandt, Jerry. J dan Kieso, Donald. E. (2008). Accounting Principle. Salemba Empat. 
Widodo, Saniman. (2007). Analisis Pengaruh Rasio Aktivitas, Rasio Profitabilitas dan Rasio Pasar terhadap Return Saham Syariah dalam Kelompok JII Tahun 20032005. Tesis. Universitas Diponegoro.

Widyarani, Fitria, (2006). Pengaruh Faktor-Faktor Fundamental dan Makro Ekonomi Terhadap Nilai Return Saham Perusahaan Miscellaneous industries Tahun 20022003. Tesis. Universitas Diponegoro. Semarang. 